\title{
Fatty Acid Binding Protein 2 Gene Polymorphism (rs1799883) in Patients with Acne Vulgaris
}

A.A.Ebrahim ${ }^{1}$, N.F.El-husseini ${ }^{2}$, A.I.Mustafa ${ }^{3}$ and F M.G.Rashad ${ }^{1}$

${ }^{1}$ Dermatology, Venereology and Andrology Dept., Faculty of Medicine,Benha Univ., Benha, Egypt

${ }^{2}$ Medical BioChemical and Molecular Biology Dept., Faculty of Medicine, Benha Univ., Benha, Egypt

${ }^{3}$ Dermatology, Venereology and Andrology Dept., Faculty of Medicine, Benha Univ., Benha, Egypt

E-Mail: mara gama1906@gmail.com

\begin{abstract}
Skin break out vulgaris(AV) may be An unending illness of the pilosebaceous unit which will be A large portion basic Throughout youth. Four variables need aid accepted will assume a way part in the improvement about skin break out lesions: overabundance sebum production, exasperates keratinization inside the follicle, colonization of the pilosebaceous conduit by Propionibacteriumacnes, and the discharge of incendiary mediators under those skin toinvestigate the companionship the middle of greasy liver tying protein-2 (rs1799883) gene polymorphism and the powerlessness will skin inflammation vulgaris. FABP2 gene polymorphism were measured clinched alongside 50 patients for av Furthermore 50 solid controls utilizing polymorphism chain reaction(. PCR). Tt Furthermore aggregate polymorphism(AT+TT) genotypes recurrence from claiming FABP2 were altogether connected with extreme evaluations from claiming skin break out patients $(\mathrm{p}<0.001)$. $\mathrm{T}$ allele indicated essentially higher recurrence "around skin break out patients when contrasted with control groups, with higher danger to create skin break out inside solid people and FABP2 (TT What's more (AT+TT) were genotypes recurrence fundamentally connected with extreme evaluations from claiming skin break out patients.
\end{abstract}

Keywords: Acne vulgaris, FABP2, PCR.

\section{Introduction}

Skin inflammation vulgaris (AV) will be An basic incessant incendiary skin ailment of the pilosebacous units influencing youths focusing on individuals' face, midsection Also back and described by framing of open Also shut comedones, erythrematous papules, pustules and lesquerella every now and again Eventually Tom's perusing nodules or pseudocyst [1].

Various variables would included in the pathophysiology about acne, including: an modification in the design of keratinization inside the pilosebaceous follicles bringing about comedone formation, a build to sebum creation which will be impacted Toward androgens, those burgeoning from claiming Propionibacterium acnes, and the creation from claiming perifollicular aggravation ,but at present hereditary and hormonal variables might additionally help skin break out structuring [2].

The mankind's FABP2 gene will be placed In Chr4q28-q31. Three saved domains of 14 bp are placed in the 50 -flanking district of FABP2 which particularly tie to atomic proteins[3].

FABP-2 gene need An part in the uptake, intracellular digestion system Also discharge about long chain unsaturated fat acids [4].

\section{Material and methods}

This similar instance control investigation incorporated 50 patients for skin inflammation vulgaris Furthermore 50 healthy, period and sex matched controls going to those dermatology outpatient facility toward Benha school Hospital, Benha, egypt from september 2018 should december 2018. Members offered their educated composed assent in the recent past enrolment and the investigation might have been sanction by the exploration morals panel to staff from claiming Medicine, Benha school.

\subsection{History taking}

Patients' demographic information were recorded: name, period What's more conjugal status. A point by point history might have been taken starting with patients in regards to onset, course, span Also repeat about skin break out. Solicit over medicinal issues including whatever systemic or skin illnesses or medication regardless admission complex.

\section{2 Cinical examination}

Finish general examination might have been finished including form impostor list.

Full general examination on avoid cohorted systemic illnesses for example, diabetes mellitus, What's more different incendiary diseases, point by point dermatological examination; on assess clinical variant, seriousness of av Furthermore vicinity about skin break out scars. Patients were isolated as 
stated by GAGS under three groups, gentle (10 patients), moderate (10 patients) Also extreme (10 patients).

\section{3 blood samples}

Venous blood specimens $(3 \mathrm{ml})$ were gathered starting with both tolerant Also control subjects under complete aseptic states inEDTA holding tubes. The blood might have been utilized to dna extraction, and the concentrated dna might have been saved In $80^{\circ} \mathrm{C}$ until those examination from claiming FABP2 gene polymorphism.

\subsection{Statistical analysis}

Table (1) Comparison between control and Acne patients regarding. FABP2genotypes and alleles
The collected data were tabulated and analyzed using SPSS version 16 soft ware (SpssInc, Chicago, ILL Company).

\section{Results and discussion \\ 3.1 Laboratory results}

Those current examine might have been conveyed out around 50 patients for skin inflammation vulgaris. The control assembly incorporated 50 sound subjects.

There might have been An statistically critical higher in the FABP2 gene polymorphism to patients over controls Table (1).

\begin{tabular}{|c|c|c|c|c|c|c|c|c|}
\hline \multirow[t]{2}{*}{ Variable } & \multicolumn{2}{|c|}{$\begin{array}{c}\text { Control } \\
\mathbf{n}=50\end{array}$} & \multicolumn{2}{|c|}{$\begin{array}{l}\text { Acne } \\
n=50\end{array}$} & \multirow[t]{2}{*}{$\mathbf{p}$} & \multirow[t]{2}{*}{ OR } & \multirow{2}{*}{\multicolumn{2}{|c|}{$95 \% \mathrm{CI}$}} \\
\hline & $\mathbf{N}$ & $\%$ & $\mathbf{N}$ & $\%$ & & & & \\
\hline \multicolumn{9}{|l|}{ Gentypes } \\
\hline $\mathbf{A A}$ & 24 & 48 & 18 & 36 & & 1 & \multicolumn{2}{|c|}{ (Reference) } \\
\hline AT & 25 & 50 & 23 & 46 & 0.631 & 1.136 & 0.675 & 1.913 \\
\hline TT & 1 & 2 & 9 & 18 & 0.011 & 4.313 & 1.399 & 13.297 \\
\hline $\mathbf{A T}+\mathbf{T T}$ & 26 & 52 & 32 & 64 & 0.224 & 1.363 & 0.827 & 2.248 \\
\hline \multicolumn{9}{|l|}{ Alleles } \\
\hline $\mathbf{A}$ & 73 & 73 & 59 & 59.0 & & 1 & \multicolumn{2}{|c|}{ (Reference) } \\
\hline $\mathbf{T}$ & 27 & 27 & 41 & 41.0 & 0.037 & 1.879 & 1.037 & 3.405 \\
\hline
\end{tabular}

\subsection{Discussion}

Skin inflammation vulgaris will be An as a relatable point skin ailment described by hormonally interceded sebum again production, follicular hyperkeratinization What's more unending aggravation of the pilosebaceous unit [5].

Greasy liver tying protein 2 (FABP2) need arole in the uptake, intracellular digestion system What's more discharge for in length chain greasy acids. Huge numbers polymorphisms done FABP2 gene need generally joined for metabolic phenotypes[6].

Those point about this contemplate might have been with research those Acquaintanceship between FABP2 gene polymorphism, Also danger about AVand those powerlessness with skin inflammation vulgaris.

This consider incorporated 50 patients enduring starting with av. Clinched alongside addition, 50 Obviously solid people from claiming matched age, sex Furthermore BMI Concerning illustration a control one assembly. At patients were chose from those outpatient facility about dermatology section from claiming Benha college healing centers. Those ponder might have been affirmed Toward the neighborhood morals panel on exploration directing, including mankind's subjects of
Benha staff for medication. Educated assent might have been acquired starting with each single person in the recent past example gathering.

Accoording on effects of the current study, might have been FABP2 (TT Also (AT+TT) were genotypes recurrence altogether connected with extreme evaluations about skin break out patients.

Additionally in thisstudy , $\mathrm{T}$ allele indicated essentially higher recurrence Around skin break out patients At contrasted with control groups, with higher danger to create skin break out inside solid control subjects.

In spite of those part of FABP2 gene polymorphism On metabolic Furthermore Weight might have been appreciated, its association in the pathogenesis for skin break out need not been great elucidated. However, An offering from claiming confirmation recommends those pathogenic part of FABP2 gene polymorphism On skin break out. To example, tnf $\alpha$ is essential modulator for gene expression [7].

Tnf $\alpha$ alsoplays a paramount part over a lot of people phases in the pathogenesis for $\mathrm{AV}$, and is consideredone of the proinflammatory cytokines that is critically vital in the regulation for MMP actuation in the dermis Throughout skin break out inflammation [8]. 
Of the best about our knowledge, no distributed investigations were found will look at the outcomes the middle of av patients concerning serum lipocalin2 levels [9].

\section{Conclusion}

Our effects indicated that those $t$ allele indicated essentially higher recurrence Around skin break out patients At contrasted with control groups, with higher danger to create skin break out inside solid people and FABP2 (TT What's more (AT+TT) were genotypes recurrence essentially connected with extreme evaluations about skin break out patients.

\section{References}

[1]P. Toossi, Z.Azizian, H. Yavari, T.H. Fakhim, S.H.S. Amini and R. Enamzade, Serum 25-hydroxy vitamin D levels in patients with acne vulgaris and its association with disease severity. Clinical Cases in Mineral and Bone Metabolism: The Official Journal of the Italian Society of Osteoporosis, Mineral Metabolism, and Skeletal Diseases,vol.12(3), pp.23842,2015.

[2]A.M. Layton, Optimal management of acne to prevent scarring and psychological sequelae. American Journal of Clinical Dermatology, vol.2(3), pp.135-41,2001.

[3] S.Harvey , CG.Martínez-Moreno , M .Luna $\mathrm{M}$ and $\mathrm{C}$. Arámburo $\mathrm{C}$, Autocrine/paracrine roles of extra pituitary growth hormone and prolactin in health and disease: An overviewin health and disease:
An overview. Gen Comp Endocrinol,vol.220, PP.103-111,2013

[4] M. Furuhashi, S. Saitoh, K. Shimamoto and $\mathrm{T}$ Miura,Fatty acid-binding protein 4 (FABP4): pathophysiological insights and potent clinical biomarker of metabolic and cardiovascular diseases, Clin Med Insights Cardiol, vol.8(3), pp.23-33, 2015.

[5] J.J. Lai, P. Chang, K.P. Lai, L. Chen and C. Chang, The role of androgen and androgen receptor in the skin-related disorders, Arch Dermatol Res, vol.304(7), pp.499-510, 2012.

[6] ML.Mansego , F.Martínez, MT MartínezLarrad , C.Zabena C, G.Rojo ,Common variants of the liver fatty acid binding protein gene influence the risk of type 2 diabetes and insulin resistance in Spanish population', PLoS ONE,vol.7(3), PP.e31853-12., 2012.

[7]G.S Hotamisligil and D A Bernlohr Metabolic functions of FABPsmechanisms and therapeutic implication. Nature Reviews Endocrinology, Vol.11(10), PP.592,2015.

[8]JJ McCarthy, HL McLeod andG Ginsburg G S Genomic medicine: a decade of successes, challenges, and opportunities', Science translational medicine, Vol.5(189), PP.189sr4-189sr4,2013.

[9] J. Kim, M.T. Ochoa, S.RKrutzik,O. Takeuchi, S. Uematsu, A.J. Legaspi et al., Activation of toll-like receptor 2 in acne triggers inflammatory cytokine responses, $\mathrm{J}$ Immunol, vol.169(3) , PP.1535-1541, 2002. 